PROBLEMS

OF MANAGEMENT

IN THE $21^{\text {st }}$ CENTURY

Volume 2, 2011

\title{
COMPETENCE REQUIREMENT DETERMINATION AND DEVELOPMENT IN SUPPLY CHAINS
}

\author{
Zoltán Kovács, Beáta Pató \\ University of Pannonia, Veszprém, Hungary \\ E-mail: kovacsz@gtk.uni-pannon.hu, patog@vnet.hu \\ Noémi Elbert \\ Continental Teves, Frankfurt, Germany \\ E-mail: Noemi.Elbert@gmx.de
}

\begin{abstract}
While production of products became more focused, activities at other location in supply chains are getting to be more complex, diverse. It means that work requires more competencies than before. This paper focuses on two issues of human resources: (1) Individual competence requirements in supply chains. There are more sources for identification competence need: determination from tasks, asking employers, national regulation of professional exams (learning outcome requirements), existing job descriptions. Authors give examples for all. Results show that general competencies have greater importance than it was expected. (2) Case studies available for training purposes in order to develop competencies. They present the related results of three EU projects. During NOVALOG project they redefined jobs, indentified competencies, worked out innovative training case studies. ITS-IT project resulted case studies on operation intermodal terminals. The presently running CENTRAL project updates NOVALOG's results and go further when works out concrete training modules.

Findings also give an overall picture of the dominant activities and tasks on different hierarchical levels and areas of supply chains in Hungary.
\end{abstract}

Key words: case study, CENTRAL project, competencies, HR in logistics.

\section{Introduction}

The basic nature of market economy is competition. There is a competition between individuals, products and companies. The playfield of competition has become larger, the competition is often global. According to Martin Christopher: "supply chains compete, not companies" In these circumstances competencies are important factors for success.

\section{Competencies}

There are many competence approaches and models. McClelland (1973) regards competencies as significant predictors of employee performance and success, where academic aptitude and knowledge content are equally important From a practical point of view competency is the capability of applying or using knowledge, skills, abilities, behaviours, and personal characteristics to successfully perform critical work tasks, specific functions, or operate in a given role or position. Personal characteristics may be mental/intellectual/cognitive, social/ emotional/attitudinal, and physical/psychomotor which attribute vitally to perform the job (Dubois, 1993; Lucia \& Lepsinger, 1999). Boyatzis (1982) and Fogg (1999) added internal and 
external constraints, environments, and relationships to this definition.

In the literature there are different classifications. One of the most commonly used grouping is where competences consist of knowledge, skills, abilities (KSAs) (Veres, Locklear $\&$ Sims, 1990). Also there are studies related to competence requirements, competence profiles. (Bergenhenegouwen, Horn \& Mooijman, 1997; Meiner, 2001, Sandbeg, 2002, Sanghi, 2004, Halasz, de Mola \& Carterd, 1993).

Different competence profiles for specific jobs are also published. APICS published specific supply chain manager and material manager competency models. (APICS, 2011)

However not only the correctness, but efficiency of competency analysis is also important. It requires gathering information, judging importance of factors and formulating the profile. All of these activities are time consuming. Chong, Ho, Tan. \& Ng, (2000) suggest a model for competency analysis, which provides a resource-effective approach to HR planning, facilitates training and development, and sets objective industry competence standards that can raise overall professionalism. Their approach is first to understand what constitutes work, to articulate a standard taxonomy of knowledge, skills and attitudes (KSAs), and then to develop scaled measures for each set of KSAs. These would be matched to each job component of work to make the link between required competencies and nature of work explicit. They use visuals (a kind of radar diagram, they named it C-plot) to present the competence profiles. (Figure 1.)

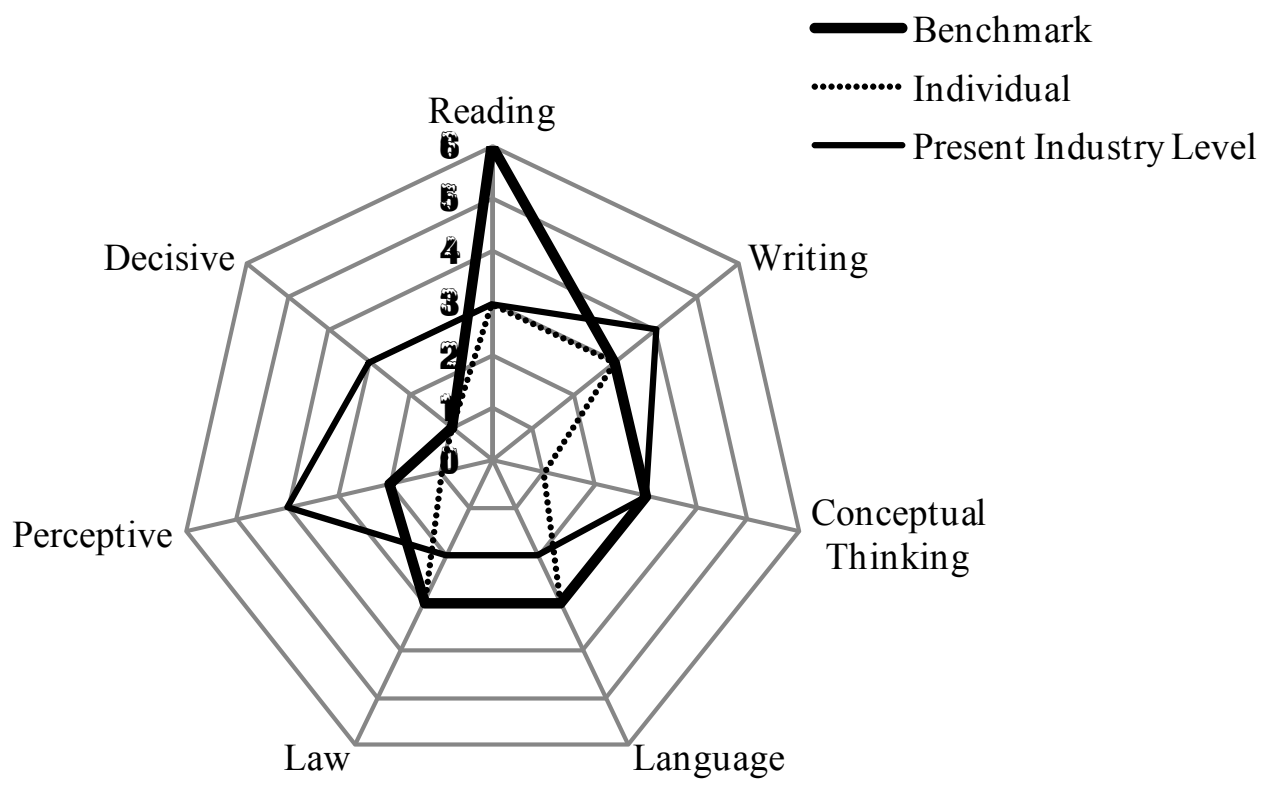

Figure 1: A competence profile. (Chong, Ho, Tan. \& Ng, (2000).

\section{Requirements in Supply Systems}

In last decade the most prominent trends in supply systems were the followings:

Enforcement of supply chain approach. This means that participants need to have more focus on the whole process than they did in the past. In this context the objective is not only the successful movement, storage and supply of receiver but the business success of the whole system. There is sensitive task, activity, cost and risk sharing between organisations and individuals along the chain.

Restructuring of jobs. As a consequence of the above mentioned trend, the content of jobs is changing. New jobs were created and the content of traditional jobs were changed. 
PROBLEMS

OF MANAGEMENT

IN THE $21^{\text {st }}$ CENTURY

Volume 2, 2011

112

As low vertical integration was manufacturing firms' basic trend, other players in supply chains became more divers. For example labelling, finishing, customization activities were added to warehousing function. The growing complexity of work resulted more demanding jobs with new, sometimes more competency requirements. (Kovács, Nagy \& Pató, 2005)

\section{Jobs in Supply Chains}

There are many classifications for jobs and occupations such as: NACE, SOC, ISCO. Rosetti \& Dooley (2010) give a classification of jobs in supply chain. They used cluster analyses based on similarity of job descriptions which indicate eight different types of SCM jobs, differentiated by associated tasks as well as industry characteristics. Their second analysis shows that supply chain management is most closely aligned with sourcing and operations management

A consortia of European organisations (universities, consulting companies, professional organisation, union) developed a job structure which fits better to the existing tasks in supply chains with focus on transport. This CENTRAL nomenclature can be seen in Table 1.

Table 1. Central nomenclature.

\begin{tabular}{|l|}
\hline Group 1: Formulating \& implementing supply and waste chains strategy \\
\hline Supply Chain Manager \\
Logistics Manager \\
Logistics Analyst \\
Logistics Engineer \\
Logistics Controller \\
Logistics IT-Specialist \\
Logistics Supervisor \\
\hline Group 2: Resource Management \\
\hline Materials Manager \\
Packaging Manager \\
Purchasing/ Procurement Manager \\
Purchasing Officer \\
Purchasing Clerk \\
Stock/ Inventory Controller \\
\hline Group 3: Production Planning and Control \\
\hline Operations Manager \\
Production Planner and Controller \\
\hline Group 4: Warehousing \\
\hline Warehouse Management \\
Warehouse Manager \\
Warehouse Supervisor \\
Warehouse Operations \\
Warehouse Operator \\
Forklift Driver \\
Order Picker \\
Administrative Operations \\
Order Processing Clerk \\
Warehouse Supporting Activity (examples) \\
Maintenance Supervisor \\
Maintenance Operator \\
\hline
\end{tabular}


Transport manager/supervisor

Transport analyst

Transport IT specialist

Group 6: Managing and monitoring transport solutions

Transport agency manager

Operations manager/supervisor

Traffic planner

Fleet manager

Consignment manager

Dispatcher

Transit officer

Group 7: Haulage

Driver

Group 8: Vehicle maintenance

Maintenance planner

Maintenance manager

Workshop supervisor/ foreman

Mechanic

Car body repairerlpainter

Group 9: Compliance functions

Quality manager /advisor

Security advisor

Custom agent / broker

Contract officer/contract and procurement agent

Group 10: Other administrative functions

Clerks for administrative management of transport/logistics

Group 11: Freight forwarding

Freight consolidator

Charterer

Cargo agent

Forwarding agent/Multimodal transport organisator

Group 4: Warehousing

\section{Derivation of the Necessary Competencies}

When one tries to determine the necessary competencies the starting point is the set of objectives which is supposed to be achieved by the organisation. This analytical logic can be seen in Figure 2. 
PROBLEMS

OF MANAGEMENT

IN THE $21^{\text {st }}$ CENTURY

volume 2, 2011

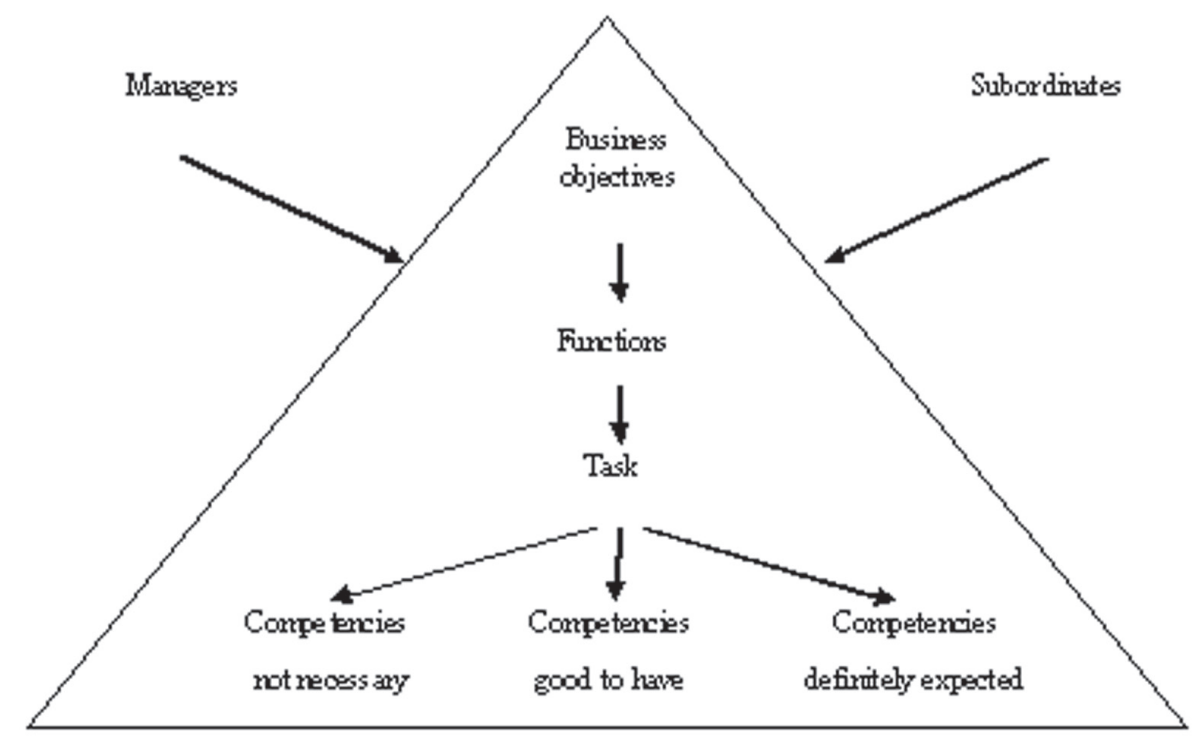

Figure 2: Competencies are generated from tasks.

This hierarchical approach is not unknown in the literature. Asimakopoulos, Dix, \& Fildes, (2011) use hierarchical task decomposition (HTA). However the application field is quite different, the principle is applicable. In their application HTA is used to describe what the expert literature has identified as the stages in producing sales forecasts. In order to evaluate this against reported scenarios and observations of actual use, they apply an approach that uses a parallel to the grammar of everyday language to represent user activities.

Other - more practical - way is to ask the managers about their competence expectations in connection with logistics jobs. Therefore authors developed a questionnaire which was filled in by 80 logistics managers.

The third method is document analysis. Authors collected more than 600 job descriptions and examined their contents.

Competency requirements can be found in different governmental documents which prescribe the required outcomes of training programs. They can be seen as elements of quality assurance. Good example for this is Halasz, de Mola \& Carterd (1993) and the Hungarian National Register of Professions.

\section{Competence Requirements}

In a local - Hungarian - study we have asked logistics managers - who are key players in supply chains - about their requirements related to managerial and subordinate competencies. Ranked results can be seen in Table 2. 
Table 2. Necessary competencies in logistics.

\section{Managerial competencies}

1 reliability

2 fairness

3 cultivated appearance

4 firmness

5 independency

6 communication skills

7 organisational skills

8 problem solving ability

9 elaborateness

10 result orientation

\section{Subordinate competencies}

1 reliability

2 fairness

3 cultivated appearance

4 firmness

5 independency

6 communication skills

7 organisational skills

8 problem solving ability

9 elaborateness

10 result orientation

Results show that in the educational system we have to give more emphasize on the general competencies. (In a previous study we analysed not only the necessary, but those competencies which are not needed for logistics jobs. Results were consistent: the overlapping of mostly less required and less frequently required competencies was large. (Kovács \& Pató, 2006).

Researches were carried out on competency requirement of specific jobs. Results were used during the transformation of Hungarian vocational training system. A summary of competences for two selected jobs can seen be as an example in Table 3.

Table 3. Competency requirements from the National Register of Professions.

\begin{tabular}{|c|c|c|}
\hline & Warehouse operator & Freight forwarder \\
\hline 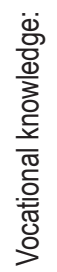 & $\begin{array}{l}\text { Material management basics, procurement, } \\
\text { receiving, placing, picking, packaging, consoli- } \\
\text { dating, shipment - procedures, tools, machines } \\
\text { and equipment, quality/conformity inspection, } \\
\text { waste management, knowledge of goods. }\end{array}$ & $\begin{array}{l}\text { Professional knowledge (traffic geography, logistics, cost- } \\
\text { and risk sharing/INCOTERMS, insurance, custom proce- } \\
\text { dures, pricing, international trade, documents, bank related } \\
\text { operations, transport modes, law, contracts, quality assur- } \\
\text { ance, knowledge of goods, packaging, warehousing tech- } \\
\text { nology, routeing, logistics centres and services, logistics } \\
\text { controlling and decision making. }\end{array}$ \\
\hline 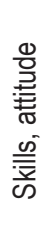 & $\begin{array}{l}\text { Idiomatic and professional speaking, and un- } \\
\text { derstanding, calculation, sense of quantities, } \\
\text { interpretation of symbols. accuracy, reliability, } \\
\text { physical strength, managebility, ability to be } \\
\text { motivated, systematic work, keeping the envi- } \\
\text { ronment clean, ability to overview. }\end{array}$ & $\begin{array}{l}\text { Ability to make decisions, ability to organise, creative way } \\
\text { of thinking, firmness, appropriate usage of knowledge and } \\
\text { competencies }\end{array}$ \\
\hline
\end{tabular}


PROBLEMS

OF MANAGEMENT

IN THE $21^{\text {st }}$ CENTURY
Volume 2, 2011

\section{Available Cases for Competence Development}

There are many ways to develop competencies. One effective method is using case studies. They are also good for sharing ideas among training organisations and disseminating results. In Hungary we were involved in two projects (NOVAG and IT-ITS) in which we developed case studies. The third (CENTRAL) project is under implementation.

\section{Innovation cases in logistics training}

During a previous European (called NOVALOG) project we gathered cases from different European countries. The structure of cases are the following:

- $\quad$ Title of the case

- Country

- Innovation type

- Job / Function

- Innovative elements

- The innovative elements.

During the project innovation was interpreted in a broad term. Innovations can be a. Organisational innovation. This category refers to organisations facilitating the execution of a job / function studied, specific structures of training supplied or to specific conditions that relate to its development.

b. Political innovation. Political innovations refer to policy initiatives in the field of employment and training by social partners, national, regional or local policymakers or other public bodies. These policies facilitate the execution of the jobs/functions studied, support or create training provision.

c. Technical innovation. These are distinguished on the basis of the tools used for training purposes.

d. Training contents and / or pedagogical approach. Training contents refers to the subjects and area covered by the training. By the pedagogical approach we refer to the way the educational process is organised.

e. Other types of innovation.

Cases from NOVALOG project and more information about the whole project can be found at www.novalog-project.org.

\section{Intermodal transport case collection}

The ITS-IT (Intermodal Transport Services - Information Tool) project objectives were:

- Targeted and reliable information for the development of an efficient and sustain-able transport system.

- Presenting intermodal transport services supply.

- Development of planning and decision making tools for transport operators and shippers.

- Support training (trainers' database, curricula development).

In the frame of ITS-IT we presented cases for intermodal transportation.

Training modules dedicated to intermodal transport are designed for the dispatchers on one hand, and the logistics and transport managers on the other hand in relation with training organisations and universities. Innovative cases and good practices of European shippers and carriers experiences already had been described.

Outcomes of this work are: 
- Best practice collection

- Trainers database

- Training modules

The structure of best practices:

- Identification of the best practice

- Alternative all (clearly) road solution

- Technical aspects

- Economic aspects

- Environmental aspects

- Lessons learnt

We worked out best practices in Hungary about:

- Baja Harbour

- Gönyü Harbour

- Budapest Intermodal Logistics Center

- Kombisztár

- Intermodal Terminal at Szeged

More about ITS-IT project can be seen at http://www.viacombi.eu/its-it_eng.pdf.

Further cases from other projects are at: http://www.eia-ngo.com/category/best-practices.

\section{Training database}

During NOVALOG project we also set up a database describing the available programmes in different countries.

For each programme, the available information are:

- Country

- Title of programme

- Brief listing of subjects

- Job/Function

- Type of training:

- Target group

- Conditions for entry

- Objectives of course

- Duration/length

- Conditions of issue of diploma/certification

- Level of qualification

$\circ \quad$ Language of delivery

- Format of course

- Company placement

- Course fee

- Contacts

Training database operates on internet at http://www.novalog-project.org.

\section{The CENTRAL project}

Central project can be seen as a kind of continuation of NOVALOG project. Although only two of the original partners - the coordinator AFT and University of Pannonia - participate, this consortium is also based on a wide European cooperation. It is true for both the countries and the nature of participants. Consulting firms, research institutes, trainers and universities participate. 
PROBLEMS

OF MANAGEMENT

IN THE $21^{\text {st }}$ CENTURY

Volume 2, 2011

Transport and logistics companies, mostly small to medium-sized companies, are present in every European country and employ more than $4 \%$ of the active population. Most European countries have an integrated concept of logistics and consider transport and logistics as a sector in its own right, whose scope needs to be defined. The changes occurring in this sector give rise to increased demand for new skills. The existing certifications and training do not meet demands in all cases, they need further development.

Programmes do not always provide a satisfactory response to the needs of employers and training bodies.

Under AFT's coordination we aim to respond to these issues within the framework of the CENTRAL project, in co-operation with European and multi-actor partners: ITL in Italy, DEKRA in Germany, the University of Pannonia in Hungary, FOREM in Belgium, Economic High School Ion Ghica in Romania, and Skills for Logistics in the UK.

Overall objectives:

- Draw up an inventory of logistics and transport jobs in Europe

- Prepare common job definitions

- Extend the NOVALOG approach, the result of a previous LEONARDO project, to all transport and logistics

- Better define the skills required for the most representative jobs

- Set up a European certification reference for the selected jobs

- Develop a training course design based on the above skills certification process which is linked to the ECVET system

Operational objectives:

1. Update the existing NOVALOG nomenclature for the representative logistics jobs

2. Extend the nomenclature to the representative transport jobs

3. Convert the nomenclature into an online database

4. Certify skills for a series of jobs by trying out the ECVET system and thereby provide a better response to the needs of employees and employers

5. Develop European training modules to increase skills in key jobs where the existing training offer has gaps

6. Transfer these innovations to the whole of the transport and logistics sector and to new countries

Expected results:

- NOVALOG nomenclature to be improved, extended to transport jobs, and converted into an online database. (This can be seen in Table 1.)

- An European certification reference, testing the ECVET system

- European training modules using transferrable credit points

Expected impact:

- Structuring of logistics and transport jobs in Europe

- Establishing the correspondences between jobs in the various countries

- Harmonising the definitions of trades in Europe

- Improving the training offer in our sector

- Cooperation, sharing of experiences and best practices between professionals Europe-wide

- Owing the harmonisation of definitions of jobs and skills and European certification, the transnational mobility of professionals can be facilitated

At present we are after the competency analysis of transport related jobs. 


\section{Conclusion}

Like in the other areas, human factor is vital in supply chains. As supply activities become more complex, job requirements widen. Beside the vital professional competencies, general competencies are getting more emphasized. There are several ways to determine the profile of necessary competencies such as task analyses, questionnaires, analysis of job descriptions and governmental regulations. Our recommendation is to apply all of them.

European level projects aim at working out common framework of competencies. Ready to use competence profiles can be found, however they need adaptation to local circumstances.

Case studies are effective tools for competency development. They are available from many sources on internet.

\section{References}

Asimakopoulos, S., Dix, A., \& Fildes, R. (2011). Using hierarchical task decomposition as a grammar to map actions in context: Application to forecasting systems in supply chain planning. International Journal of Human-Computer Studies, 69, 4, p. 234-250.

APICS (2011). Retrieved: September 18, 2011. from http://www.apics.org/sitefiles/forms/apics_supply_ chain_manager_competency_model.html

Bergenhenegouwen, G. J., Horn, H. F. K., \& Mooijman, E. A. M. (1997). Competence development - a challenge for human resource professionals: core competences of organizations as guidelines for the development of employees. Industrial and Commercial Training, Vol. 29, Issue 2, p. 55-62.

Boyatzis, R. E. (1982). The competent manager: A model for effective performance. New York: Wiley.

Chong C. L., Ho, Y. P, Tan, H. H., \& Ng, K. K. (2000). A Practical Model for Identifying and Assessing Work Competencies. Management Development Forum, Vol. 3, No. 1.

Dubois, D. D. (1993). Competency-based performance improvement: A strategy for organizational change. Amherst, MA: HRD Press, Inc.

Fogg, C. D. (1999). Implementing your strategic plan: How to turn "intent" into effective action for sustainable change. New York: American Management Association.

Halasz, I., de Mola, A.L., \& Carterd, D. (1993). Competency Profile of Public Information Officer. U.S. Department of Justice National Institute of Corrections, Retrieved 18/09/2011, from http://static.nicic. gov/Library/004615.pdf

Kovács, Z., Nagy, P., \& Pató, G. Sz. B. (2005). Knowledge and usage of OM techniques in Hungary. Operations and Competitiveness EUROMA Conference, Budapest, June 19-22, 2005.

Meiner, H. (2001). Integrierte Führungskrafteentwicklung, Zeitschrift für Unternehmensentwiklung und Industrial Engineering 50.k.1.sz.

Pató Gáborné Szűcs, B., Kovács, Z., \& Pató, G. (2006). Competencies: Required and Non-required. Studia Universitatis Babes-Bolyai, Oeconomica, LI, 1, 2006, p. 123-133.

Lucia, A. D., \& Lepsinger, R. (1999). The art and science of competency models: Pinpointing critical success factors in organizations. New York, Pfeiffer.

McClelland, D. C. (1973). Testing for competence rather than for intelligence. American Psychologist, 28, pp. 1-14.

Rossetti, C., \& Dooley, K. (2010). Job Types in The Supply Chain Management Profession. Journal of Supply Chain Management, 46, 3, p. 40-56,

Sandberg, J. (2000). Understanding human competence at work: An interpretative approach. The Academy of Management Journal, 43(1), p. 9-25. 
OF MANAGEMENT IN THE $21^{\text {st }}$ CENTURY Volume 2, 2011

Sanghi, S. (2004). The Handbook of Competency Mapping. Sage India, 2004.

Veres, J. G., Locklear, T. S., \& Sims, R. R. (1990). Job analysis in practice: A brief review of the role of job analysis in human resource management. In G. R. Ferris, K. M. Rowland, \& M. R. Buckley (Eds.) Human resource management: Perspectives and issues. Boston: Allyn and Bacon. p. 79-103.

Advised by Edit Komlósi, University of Pannonia, Veszprém, Hungary

Received: September 14, 2011

Accepted: October 26, 2011

\begin{tabular}{ll} 
Zoltán Kovács & PhD, Professor, University of Pannonia, Faculty of Economics, Department of \\
& Management, Egyetem u. 10, Veszprém, H-8200, Hungary. \\
& $\begin{array}{l}\text { E-mail: kovacsz@gtk.uni-pannon.hu } \\
\text { Website: http://wiki.gtk.uni-pannon.hu/mediawiki_en/index.php/Department_of_Ma- } \\
\text { nagement }\end{array}$ \\
Beáta Pató & $\begin{array}{l}\text { PhD, Associate Professor, University of Pannonia, Faculty of Economics, Depart- } \\
\text { ment of Management, Egyetem u. 10, Veszprém, H-8200, Hungary, } \\
\text { E-mail: patog@vnet.hu } \\
\text { Website: http://wiki.gtk.uni-pannon.hu/mediawiki_en/index.php/Department_of_Ma- } \\
\text { nagement }\end{array}$ \\
\hline Noémi Elbert & $\begin{array}{l}\text { New Product Coordinator, Continental Teves, Frankfurt, Germany. } \\
\text { E-mail: Noemi.Elbert@gmx.de }\end{array}$
\end{tabular}

